\title{
Urinary excretion of $\beta_{2}$-glycoprotein-1 (apolipoprotein $\mathrm{H}$ ) and other markers of tubular malfunction in "non-tubular" renal disease
}

\author{
F V Flynn, M Lapsley, P A Sansom, S L Cohen
}

\begin{abstract}
Aim: To determine whether urinary $\beta_{2}$-glycoprotein-1 assays can provide improved discrimination between chronic renal diseases which are primarily of tubular or glomerular origin.

Methods: Urinary $\beta_{2}$-glycoprotein-1, retinol-binding protein, $a_{1}$-microglobulin, $\boldsymbol{\beta}_{2}$-microglobulin, $\mathbf{N}$-acetyl- $\boldsymbol{\beta}$-D-glucosaminidase and albumin were measured in 51 patients with primary glomerular disease, 23 with obstructive nephropathy, and 15 with polycystic kidney disease, and expressed per mmol of creatinine. Plasma $\beta_{2}$-glycoprotein-1 was assayed in 52 patients and plasma creatinine in all 89. The findings were compared between the diagnostic groups and with previously published data relating to primary tubular disorders.
\end{abstract}

Results: All 31 patients with plasma creatinine greater than $200 \mu \mathrm{mol} / 1$ excreted increased amounts of $\beta_{2}$-glycoprotein-1, retinol-binding protein, and $a_{1}$-microglobulin, and 29 had increased $N$-acetyl$\beta$-D-glucosaminidase; the quantitites were generally similar to those found in comparable patients with primary tubular pathology. Among 58 with plasma creatinine concentrations under $200 \mu \mathrm{mol} / /$, increases in $\beta_{2}$-glycoprotein-1, retinolbinding protein, and $\alpha_{1}$-microglobulin excretion were less common and much smaller, especially in those with obstructive nephropathy and polycystic disease. The ratios of the excretion of albumin to the other proteins provided the clearest discrimination between the patients with glomerular or tubular malfunction, but an area of overlap was present which embraced those with obstructive nephropathy and polycystic disease.

Conclusions: Increased excretion of $\beta_{2}$-glycoprotein-1 due to a raised plasma concentration or diminution of tubular reabsorption, or both, is common in all the forms of renal disease investigated, and both plasma creatinine and urinary albumin must be taken into account when interpreting results. Ratios of urinary albumin: $\beta_{2}$-glycoprotein-1 greater than 1000 are highly suggestive of primary glomerular disease and those less than 40 of primary tubular disease. Used in this way, $\beta_{2}$-glycoprotein-1 assays provide superior discrimination between glomerular and tubular malfunction when compared with retinol binding protein but the best discrimination is provided by albumin: $a_{1}$-microglobulin ratios.

In recent years increased urinary excretion of retinol binding protein (RBP), $a_{1}$-microglobulin $\left(a_{1} M\right)$, or $\beta_{2}$-microglobulin $\left(\beta_{2} M\right)$ have been used as markers of proximal renal tubular malfunction. These low molecular weight plasma proteins are freely filtered at the glomerulus and normally virtually completely reabsorbed by the proximal renal tubule cells, where they are catabolised. ${ }^{1}$ Defective reabsorption accounts for their increased urinary excretion in renal tubular disorders. Unfortunately, finding them in excess is not specific to renal tubular disease because all three are excreted in increased quantity whenever the endogenous creatinine clearance is reduced-to 25-30 ml/minute in the case of RBP and $\beta_{2} \mathrm{M}^{2}$ and to less than $55 \mathrm{ml} /$ minute in the case of $a_{1} M^{3}$

Increased excretion of $\mathrm{N}$-acetyl- $\beta$-D-glucosaminidase (NAG), an enzyme found in the lysosomes of proximal renal tubule cells, should be more specific for tubular pathology because its molecular mass is large enough to preclude passage through the normal glomerular basement membrane. However, increased excretion of NAG only reflects active tubular damage and it has also been reported in patients with glomerulonephritis. ${ }^{4}$ Increased albumin excretion usually reflects glomerular disease but when the quantities are small it may be due to impaired tubular reabsorption: thus some albuminuria is regularly found in patients with renal tubular disorders.

In the course of searching for an improved protein marker of renal tubular disease we discovered that $\beta_{2}$-glycoprotein-1 $\quad\left(\beta_{2} \mathrm{G} 1\right)$ is excreted in increased quantity by patients with primary renal tubular disorders, despite its relatively high molecular mass. ${ }^{6}$ To determine whether increased excretion of $\beta_{2} \mathrm{Gl}$ might be a more specific marker for tubular malfunction than existing tests we have now investigated its excretion by patients with primary glomerular pathology, obstructive nephropathy, and polycystic kidney disease, comparing its excretion with that of albumin, RBP, $a_{1} M, \beta_{2} M$, and NAG. The study was approved by the hospital ethical committee. 


\section{Methods}

Random midstream specimens of urine and samples of blood anticoagulated were obtained from 89 patients ( 54 men and 35 women) aged between 18 and 90 years. All were under the care of a nephrologist and had had some increase in urinary protein excretion. They included 51 with a variety of diseases associated primarily with glomerular pathology, 23 with nephropathy following unequivocally documented renal tract obstruction, and 15 with radiologically confirmed polycystic kidney disease. Those with primary glomerular pathology included eight with IgA and one with IgM nephropathy eight with focal segmental glomerulosclerosis, seven with membranous nephropathy, five with minimal change nephropathy, five with renal amyloidosis, four with mesangiocapillary glomerulonephritis, and one with membranoproliferative glomerulonephritis, in all of whom the diagnosis had been confirmed by renal biopsy. Also included were six patients with overt diabetic nephropathy, three with polyarteritis nodosa, and single cases of Wegener's granulomatosis, systemic lupus erythematosus, and hypertensive nephropathy.

The urine and blood specimens were centrifuged at $1800 \times g$ for 10 minutes and the supernatant divided into portions for the different assays. All the urine fractions were frozen within four hours of collection and kept at $-20^{\circ} \mathrm{C}$ until shortly before analysis.

All the urine samples were assayed for creatinine, albumin, $\beta_{2} \mathrm{G} 1, \mathrm{RBP}, a_{1} \mathrm{M}, \beta_{2} \mathrm{M}$ and NAG, and all the plasma samples for creatinine. Plasma $\beta_{2} \mathrm{Gl}$ concentrations were measured in 52 patients. All the assays, except those for creatinine, were performed in duplicate. To reduce the effects of the different concentrations of the urine specimens and to facilitate comparison of the excretion of the different proteins, all results were expressed in mg per mmol of creatinine.

The concentration of creatinine was measured by the Jaffé reaction, using the kinetic method employed in the American Monitor
Perspective analyser. Albumin was measured by an immunoturbidimetric method with a Cobas-Bio centrifugal analyser, using the Ames "Microalb" kit from Miles Laboratories Ltd (Stoke Poges, Slough, England). $\beta_{2}$ G1 was measured by in-house methods described elsewhere, ${ }^{7}$ using a sandwich enzyme linked immunosorbent assay (ELISA) for urine assays and a radial immunodiffusion procedure for plasma measurements. RBP was measured by the ELISA method of Topping $e t a l,{ }^{8}$ and $a_{1} M$ by the ELISA procedure of Takagi et al, ${ }^{9}$ using the "Imzyne $a_{1} M$ " kit from Mast Diagnostics (Bootle, Merseyside, England). $\beta_{2} M$ was measured by a radioimmunoassay method using the $\beta_{2}$-Micro RIA kit from Pharmacia Ltd (Midsummer Boulevard, Milton Keynes, England). NAG activity was measured by a colorimetric procedure, based on the method of Yuen et al, ${ }^{10}$ using a Cobas-Bio centrifugal analyser and the kit available from Cortecs Diagnostics Ltd (Deeside Industrial Park, Clwyd, Wales).

\section{Results}

The findings in the 51 patients with chronic renal disease primarily of glomerular origin, 23 with obstructive nephropathy, and 15 with polycystic kidney disease are summarised in tables 1-3, respectively. Table 1 also cites corresponding findings from 60 patients with chronic renal tubular disorders studied earlier ${ }^{5}$ and in whom the diagnoses had been made by physicians with special expertise in the diseases concerned.

Among the 37 patients with primary glomerular pathology and a plasma creatinine of less than $200 \mu \mathrm{mol} / 1$, an increased excretion of NAG, $\alpha_{1} M, \beta_{2} \mathrm{G} 1$ and RBP was found, respectively, in $73 \%, 59 \%, 57 \%$, and $49 \%$ of the subjects. The excretion of $\beta_{2} M$ was within the reference range in 33 of the patients, but in this context it should be noted that the $\mathrm{pH}$ of the specimens was below 5.5 in 11 cases and had not been recorded in two others. When an

Table 1 Urinary excretion of five plasma proteins and of NAG by 51 patients with chronic glomerular pathology, 37 with plasma creatinine concentrations under 200 (group G1) and 14 with concentrations above 200 umolll (group G2)

\begin{tabular}{|c|c|c|c|c|c|c|c|c|}
\hline & & \multicolumn{3}{|l|}{ All patients } & \multicolumn{4}{|c|}{ Patients with increased excretion } \\
\hline & & \multicolumn{3}{|c|}{ Mean and range of excretion* } & \multicolumn{2}{|c|}{$\%$ of group } & \multicolumn{2}{|l|}{ Mean excretion } \\
\hline $\begin{array}{l}\text { ALB } \\
\beta_{2} G 1 \\
\text { RBP } \\
a_{1} M \\
\beta_{2} M \\
\text { NAG }\end{array}$ & $\begin{array}{l}(G 1) \\
190 \\
0 \cdot 121 \\
0.079 \\
1.4 \\
0.06 \\
56.2\end{array}$ & $\begin{array}{l}(<0.05-760) \\
(0.008-1.54) \\
(0.003-1.36) \\
(<0.01-8.7) \\
(0.007-0.91) \\
(8-144)\end{array}$ & $\begin{array}{c}(G 2) \\
322 \\
3 \cdot 97 \\
2 \cdot 26 \\
9 \cdot 3 \\
3 \cdot 17 \\
127\end{array}$ & $\begin{array}{l}(86-1100) \\
(0 \cdot 059-18 \cdot 7) \\
(0 \cdot 084-13 \cdot 2) \\
(2 \cdot 6-28 \cdot 3) \\
(0 \cdot 025-20 \cdot 1) \\
(26 \cdot 6-576)\end{array}$ & $\begin{array}{l}\text { (G1) } \\
97 \% \\
57 \% \\
49 \% \\
59 \% \\
11 \% \\
73 \%\end{array}$ & $\begin{array}{l}\text { (G2) } \\
100 \% \\
100 \% \\
100 \% \\
100 \% \\
71 \% \\
100 \%\end{array}$ & $\begin{array}{l}\text { (G1) } \\
217 \times \text { URL } \\
5.6 \times \text { URL } \\
9.5 \times \text { URL } \\
2.9 \times \text { URL } \\
3.2 \times \text { URL } \\
2.9 \times \text { URL }\end{array}$ & $\begin{array}{l}\text { (G2) } \\
358 \times \text { URL } \\
115 \times \text { URL } \\
141 \times U R L \\
13 \times \text { URL } \\
44 \times \text { URL } \\
5.1 \times \text { URL }\end{array}$ \\
\hline $\begin{array}{l}\text { ALB } \\
\beta_{2} \text { G1 } \\
\text { RBP } \\
a_{1} M \\
\beta_{2} M \\
\text { NAG }\end{array}$ & $\begin{array}{c}(T 1) \\
15 \cdot 6 \\
0.940 \\
5 \cdot 42 \\
4 \cdot 5 \\
2 \cdot 7 \\
36.7\end{array}$ & $\begin{array}{l}(<0.05-118) \\
(0 \cdot 011-30 \cdot 8) \\
(0.004-184) \\
(0 \cdot 1-62 \cdot 5) \\
(0 \cdot 01-68 \cdot 7) \\
(1 \cdot 5-176)\end{array}$ & $\begin{array}{c}\text { (T2) } \\
64 \cdot 7 \\
4.96 \\
7 \cdot 31 \\
11 \cdot 7 \\
7 \cdot 38 \\
52 \cdot 5\end{array}$ & $\begin{array}{l}(2 \cdot 2-197) \\
(0 \cdot 025-21 \cdot 9) \\
(0 \cdot 049-20 \cdot 7) \\
(2 \cdot 6-28 \cdot 3) \\
(0 \cdot 06-19 \cdot 4) \\
(12 \cdot 7-121)\end{array}$ & $\begin{array}{l}\text { (T1) } \\
83 \% \\
79 \% \\
75 \% \\
75 \% \\
40 \% \\
50 \%\end{array}$ & $\begin{array}{l}\text { (T2) } \\
100 \% \\
92 \% \\
100 \% \\
100 \% \\
92 \% \\
90 \%\end{array}$ & $\begin{array}{l}(T 1) \\
21 \times \text { URL } \\
34 \times \text { URL } \\
452 \times \text { URL } \\
8.5 \times \text { URL } \\
68 \times \text { URL } \\
2.4 \times \text { URL }\end{array}$ & $\begin{array}{l}(T 2) \\
72 \times U R L \\
157 \times U R L \\
457 \times U R L \\
17 \times U R L \\
80 \times \text { URL } \\
2.3 \times \text { URL }\end{array}$ \\
\hline
\end{tabular}

Corresponding findings applying to 60 patients with chronic renal tubular disorders $(n=5)$ are included for comparison, 48 with plasma creatinine concentrations under 200 (group T1) and 12 with concentrations above $200 \mu \mathrm{mol} / /$ (group T2). URL $=$ with plasma creatinin upper reference limit.

$\star$ Protein values are in $\mathrm{mg}$ and enzyme activity in $\mu \mathrm{mol}$ of substrate hydrolysed per hour, and all results are expressed per mmol of urinary creatinine, and the reference ranges applying are:

albumin $(A L B)=\left\langle 0.9 ; a_{1}\right.$-microglobulin $\left(a_{1} M\right)=<0.7 ; \beta^{2}$-glycoprotein $1\left(\beta_{2} G 1\right)=0.0069-0.0345 ; \beta_{2}$-microglobulin $\left(\beta^{2} M\right)=$ $<0.1$; retinol binding protein $(\mathrm{RBP})=0.001-0.016 ; \mathrm{N}$-acetyl- $\beta$-D-glucosaminidase (NAG) $=<25$. 
Table 2 Urinary excretion of five plasma proteins and of NAG by 23 patients with obstructive nephropathy, 13 with

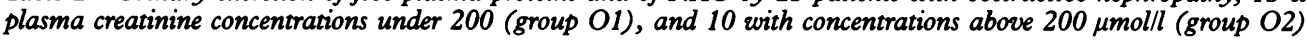

\begin{tabular}{|c|c|c|c|c|c|c|c|c|c|}
\hline & & \multicolumn{3}{|l|}{ All patients } & \multicolumn{5}{|c|}{ Patients with increased excretion } \\
\hline & & \multicolumn{3}{|c|}{ Mean and range of excretion * } & \multicolumn{2}{|c|}{$\%$ of group } & \multicolumn{3}{|l|}{ Mean excretion } \\
\hline & $(\mathrm{O} 1)$ & & $(\mathrm{O} 2)$ & & (O1) & $(\mathrm{O} 2)$ & (O1) & $(\mathrm{O} 2)$ & \\
\hline $\begin{array}{l}\text { ALB } \\
\beta_{2} G 1 \\
\text { RBP } \\
a_{1} M \\
\beta_{2} M \\
\text { NAG }\end{array}$ & $\begin{array}{l}9 \cdot 7 \\
0.056 \\
0.036 \\
0.5 \\
0.075 \\
29 \cdot 5\end{array}$ & $\begin{array}{l}(<0.05-24) \\
(0.019-0.108) \\
(0.003-0.153) \\
(<0.01-1.4) \\
(0.014-0.19) \\
(8.7-87)\end{array}$ & $\begin{array}{c}167 \\
1 \cdot 38 \\
7 \cdot 38 \\
7 \cdot 20 \\
6 \cdot 21 \\
63 \cdot 3\end{array}$ & $\begin{array}{l}(6 \cdot 2-389) \\
(0 \cdot 067-3 \cdot 86) \\
(3 \cdot 15-15 \cdot 4) \\
(2 \cdot 5-13 \cdot 5) \\
(0 \cdot 028-17 \cdot 7) \\
(19 \cdot 5-237)\end{array}$ & $\begin{array}{l}85 \% \\
62 \% \\
46 \% \\
31 \% \\
31 \% \\
46 \%\end{array}$ & $\begin{array}{r}100 \% \\
100 \% \\
100 \% \\
100 \% \\
90 \% \\
80 \%\end{array}$ & $\begin{array}{r}12.8 \times U R L \\
2.4 \times U R L \\
4.3 \times U R L \\
1.7 \times U R L \\
1.5 \times U R L \\
1.8 \times U R L\end{array}$ & $\begin{array}{c}185 \\
40 \\
461 \\
10 \\
62 \\
2 \cdot 5\end{array}$ & $\begin{array}{l}\times \text { URL } \\
\times \text { URL } \\
\times \text { URL } \\
\times \text { URL } \\
\times \text { URL } \\
\times \text { URL }\end{array}$ \\
\hline
\end{tabular}

Table 3 Urinary excretion of five plasma proteins and of NAG by 15 patients with polycystic kidney disease, 8 with plasma creatinine concentrations under 200 (group P1), and 7 with concentrations above $200 \mu$ molll (group P2)

\begin{tabular}{|c|c|c|c|c|c|c|c|c|c|}
\hline & & \multicolumn{3}{|l|}{ All patients } & \multicolumn{5}{|c|}{ Patients with increased excretion } \\
\hline & & \multicolumn{3}{|c|}{ Mean and range of excretion* } & \multicolumn{2}{|c|}{$\%$ of group } & \multicolumn{3}{|c|}{ Mean excretion } \\
\hline & (P1) & & (P2) & & (P1) & (P2) & (P1) & (P2) & \\
\hline $\begin{array}{l}\text { ALB } \\
\beta_{2} G 1 \\
\text { RBP } \\
a_{1} M \\
\beta_{2} M \\
\text { NAG }\end{array}$ & $\begin{array}{l}5.5 \\
0.043 \\
0.013 \\
0.5 \\
0.031 \\
22.0\end{array}$ & $\begin{array}{l}(0.7-23) \\
(0.02-0.075) \\
(0.007-0.036) \\
(0.1-1 \cdot 3) \\
(0.021-0.038) \\
(8.5-70)\end{array}$ & $\begin{array}{c}115 \\
1 \cdot 32 \\
17 \cdot 5 \\
28 \cdot 3 \\
10 \cdot 2 \\
78 \cdot 5\end{array}$ & $\begin{array}{l}(8 \cdot 4-527) \\
(0 \cdot 049-4 \cdot 07) \\
(0 \cdot 201-57 \cdot 3) \\
(3 \cdot 0-118) \\
(0 \cdot 103-32 \cdot 5) \\
(36 \cdot 5-191)\end{array}$ & $\begin{array}{r}88 \% \\
63 \% \\
25 \% \\
38 \% \\
0 \% \\
25 \%\end{array}$ & $\begin{array}{l}100 \% \\
100 \% \\
100 \% \\
100 \% \\
100 \% \\
100 \%\end{array}$ & $\begin{array}{l}7.1 \times \text { URL } \\
1.6 \times \text { URL } \\
1.7 \times \text { URL } \\
1.6 \times \text { URL } \\
2.0 \times \text { URL }\end{array}$ & $\begin{array}{c}128 \\
38 \\
1090 \\
40 \\
102 \\
3 \cdot 1\end{array}$ & $\begin{array}{l}\times \text { URL } \\
\times \text { URL } \\
\times \text { URL } \\
\times \text { URL } \\
\times \text { URL } \\
\times \text { URL }\end{array}$ \\
\hline
\end{tabular}

increased excretion was present, the magnitude of the increase decreased in the order $\mathrm{RBP}>\beta_{2} \mathrm{G} 1>\beta_{2} \mathrm{M}>a_{1} \mathrm{M}$ and NAG. Six of the subjects had a normal excretion of $\beta_{2} \mathrm{Gl}$, RBP, $a_{1} M, \beta_{2} M$ and NAG and three an increased excretion of all these constituents. Eleven were excreting increased quantitites of $\beta_{2} \mathrm{G} 1, \mathrm{RBP}$, and $a_{1} \mathrm{M}$, and 13 increased amounts of two of these three proteins. The incidence and magnitude of the increase in excretion of $\beta_{2} \mathrm{Gl}$ and low molecular weight proteins, but not NAG, was appreciably less than in patients with renal disease primarily of tubular origin, and albumin excretion was on average 12 times higher.

All 14 patients with primary glomerular pathology and a plasma creatinine above $200 \mu \mathrm{mol} / 1$ were excreting increased quantities of albumin, $\beta_{2} G 1, R B P, a_{1} M$ and NAG, the first three usually in substantially increased amounts. Ten had raised amounts of $\beta_{2} \mathbf{M}$, but among the four patients in whom the excretion was within the reference range the $\mathrm{pH}$ of the urine specimens was below 5.5 in three. The excretion of NAG, $\beta_{2} \mathrm{Gl}$, and the low molecular weight proteins was generally much greater than in those with a plasma creatinine of less than $200 \mu \mathrm{mol} / 1$ : the average excretion of $\beta_{2} M$ was 53 times greater, and the corresponding figures for $\beta_{2} G 1, R B P, a_{1} M$, NAG and albumin were, respectively, 33, 29, 7, 2.3 and 1.7 times greater. When compared with patients with primary tubular pathology and similar plasma creatinine concentrations, this group excreted five times as much albumin, twice as much NAG, and about two thirds the quantity of the other proteins.

Among the 13 patients with obstructive nephropathy and a plasma creatinine under $200 \mu \mathrm{mol} / 1$ the incidence of increased excretion of the constituents measured was generally less than in the patients with primary glomerular and primary tubular pathology and its magnitude consistently so. Three had normal excretion of all the constituents measured except albumin, and three had increased excre- tion of $\beta_{2} \mathrm{G} 1, \mathrm{RBP}$, and $a_{1} \mathrm{M}$. Of the 10 with obstruction and a plasma creatinine exceeding $200 \mu \mathrm{mol} / 1$, the excretion of all the constituents measured was raised in seven and the output of $\beta_{2} \mathrm{G} 1, \mathrm{RBP}$, and $a_{1} \mathrm{M}$ was increased in all. The amounts excreted were less than in patients with primary glomerular and primary tubular pathology except in the case of RBP, and sometimes $\beta_{2} M$, which reached exceptionally high values in the six patients with plasma creatinine concentrations above $600 \mu \mathrm{mol} / 1$.

Among the eight patients with polycystic kidney disease and a plasma creatinine concentration of less than $200 \mu \mathrm{mol} / 1$, the incidence and magnitude of increased excretion of the constituents measured was less than that found in patients with primary glomerular and primary tubular pathology. Two had $\beta_{2} \mathrm{Gl}, \mathrm{RBP}$, $a_{1} M$ and NAG all within the reference range, one had all the measured constituents raised, and one had increased excretion of $\beta_{2} \mathrm{G} 1, \mathrm{RBP}$, and $a_{1} M$. All seven who had a plasma creatinine greater than $200 \mu \mathrm{mol} / 1 \mathrm{had}$ increases of all the constituents measured, the rise in RBP, $a_{1} M$, and $\beta_{2} M$ being particularly pronounced in the four subjects with plasma creatinine concentrations in excess of $600 \mu \mathrm{mol} / 1$.

Figure 1 shows the excretion of $\beta_{2} \mathrm{Gl}, \mathrm{RBP}$, $a_{1} M$ and NAG by each of the 89 patients studied, plotted against their plasma creatinine concentration. These plots show that in all three diagnostic groups, when the plasma creatinine concentration exceeds $200 \mu \mathrm{mol} / \mathrm{l}$, the excretion of the proteins is consistently raised and, with few exceptions, the same is true of urinary NAG activity. That the excretion of $\beta_{2} \mathrm{Gl}$ may be reflecting an increase in the plasma concentration can be deduced from fig 2, where the plasma $\beta_{2} \mathrm{Gl}$ concentrations found in 52 patients are plotted against their plasma creatinine concentrations.

Figure 3 shows the excretion of $\beta_{2} \mathrm{G} 1, \mathrm{RBP}$, $a_{1} M$ and NAG by each of the 58 patients whose plasma creatinine concentrations were less than $200 \mu \mathrm{mol} / 1$, plotted against their 

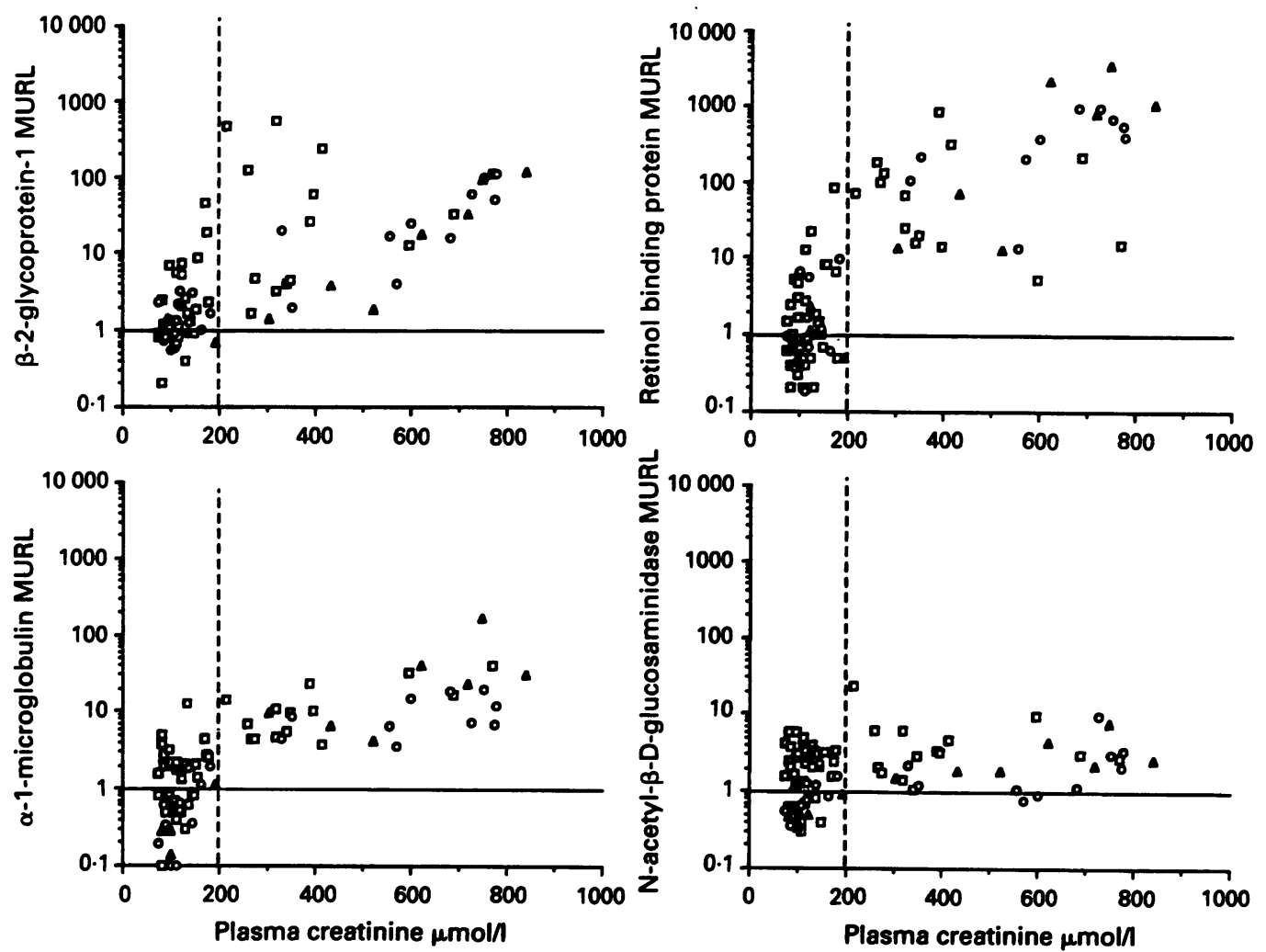

Figure 1 Plots showing correlation between plasma creatinine concentration and urinary excretion of $\beta_{2} G 1, R B P, a, M$, and NAG among 51 patients with primary glomerular pathology ( $\square), 23$ with obstructive nephropathy (O), and 15 with polycystic kidney disease $(\Delta)$. In each the horizontal line marks the upper reference limit for the urinary constituent and the vertical line the $200 \mu \mathrm{molll}$ creatinine concentration. The urinary values are plotted as multiples of the upper reference limit (MURL) on logarithmic scales.

albumin excretion. A tendency for the excretion of $\beta_{2} \mathrm{G} 1, a_{1} \mathrm{M}$, and NAG to rise in parallel with increasing albumin loss can be seen but the correlation is poor. Figure 4 shows the ratios of the excretion of albumin to that of $\beta_{2} \mathrm{Gl}, \mathrm{RBP}$, and $a_{1} \mathrm{M}$ among the patients with primary glomerular pathology, plotted alongside the corresponding results obtained from those with obstructive nephropathy and polycystic kidney disease, and those derived from patients with chronic renal tubular disorders studied earlier. ${ }^{5}$ In a few cases albumin excretion values close to zero precluded calculation of the ratios. The figure shows the expected tendency for the proportion of albumin to be higher among those with primary glomerular

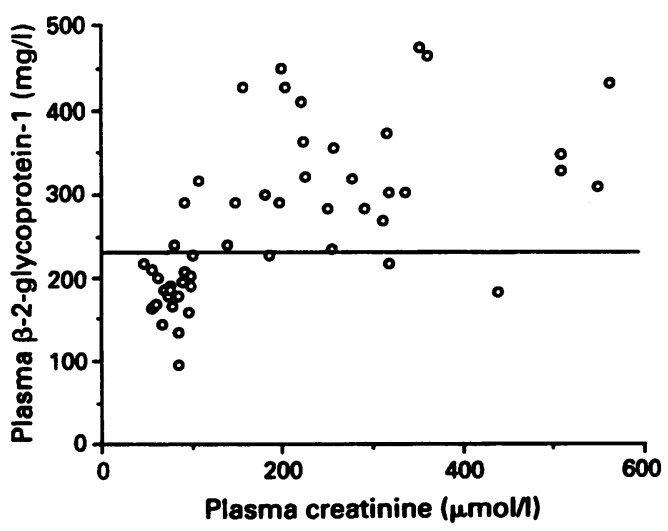

Figure 2 Plot showing the correlation between plasma concentrations of creatinine and $\beta_{2} G 1$ among 52 patients. The horizontal line marks the upper reference limit for the protein measurement. pathology and that the ratio of urinary albumin: $a_{1} M$ gives the best discrimination between patients with primary glomerular and tubular pathology. Figure 4 also shows that the ratios of albumin: $\beta_{2} \mathrm{G} 1$ and albumin: $a_{1} M$ among the patients with obstructive nephropathy and polycystic kidney disease occupy an intermediate position between that of patients with primary glomerular and primary tubular pathology.

\section{Discussion}

The results reported confirm that many patients with chronic renal disease primarily of glomerular origin excrete increased quantities of the low molecular weight proteins that are used to detect renal tubular disorders, and establish that the same applies to $\beta_{2} \mathrm{Gl}$. The amounts excreted by the patients with plasma creatinine concentrations above $200 \mu \mathrm{mol} / 1$ are generally comparable with those we found in patients with chronic renal tubular disorders, and $\beta_{2} \mathrm{G} 1$ assays do not themselves offer superior discrimination between conditions that primarily affect the glomeruli or the tubules. The relatively low incidence of increased $\beta_{2} M$ excretion found in the patients with primary glomerular disease almost certainly does not indicate any greater specificty of this protein for detecting tubular malfunction but rather reflects its instability in acid urine ${ }^{11}$ which can account for appreciable degradation taking place during the time that the urine is held in the bladder. ${ }^{12}$ Thus three of the patients 

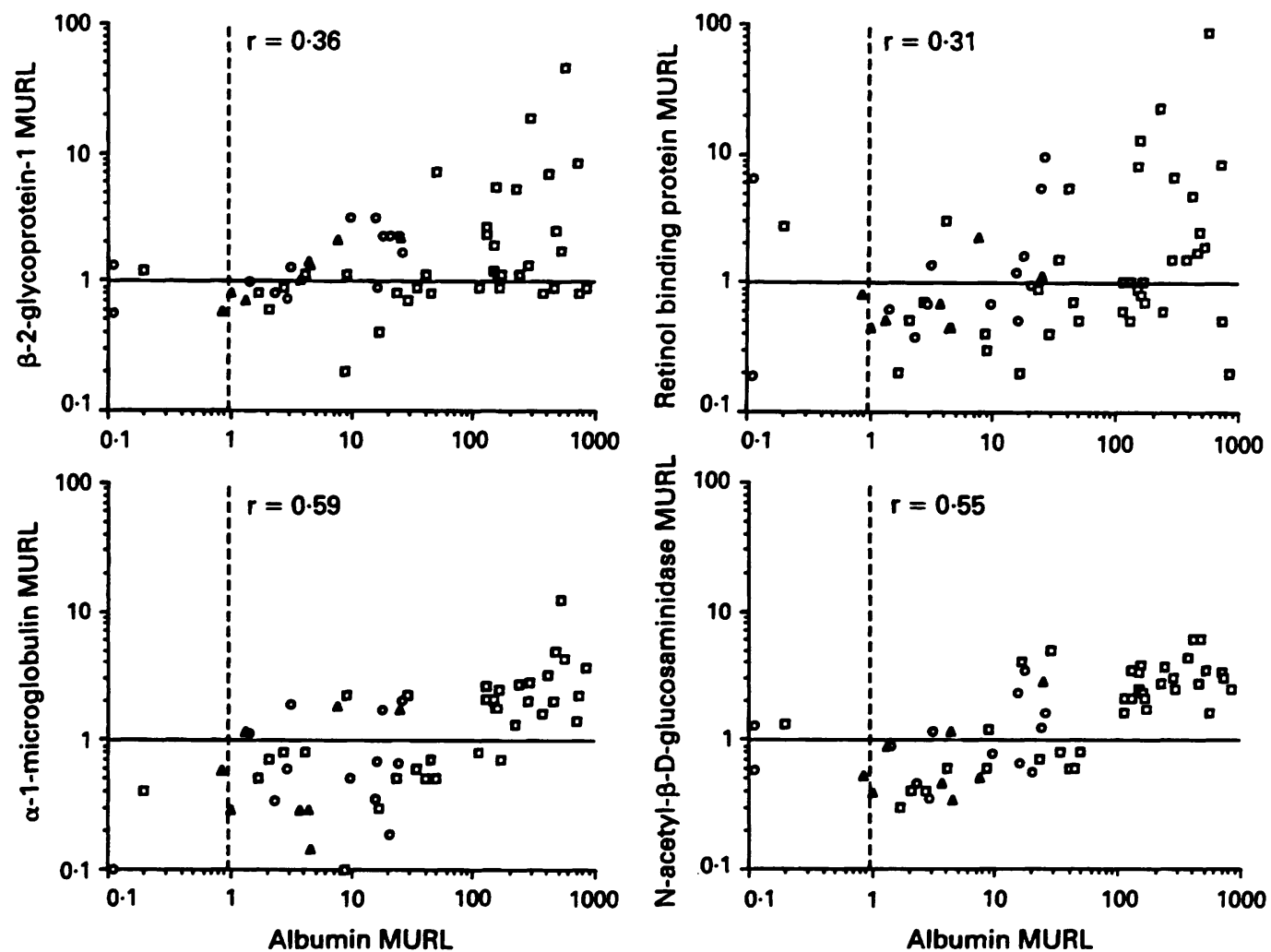

Figure 3 Plots showing the correlation between urinary excretion of albumin and $\beta_{2} G 1, R B P, a_{1}-M$, and $N A G$ among 37 patients with primary glomerular pathology $(\square), 13$ with obstructive nephropathy $(O)$, and eight with polycystic kidney disease $(\triangle)$, all with plasma creatinine concentrations below $200 \mu$ molll. The lines mark the upper reference limits. All results are plotted as multiples of the upper reference limit (MURL) on logarithmic scales.

with a plasma creatinine concentration exceeding $200 \mu \mathrm{mol} / 1$ and an apparently normal $\beta_{2} M$ excretion had provided urine specimens of pH 5-6. The infrequency of finding a raised $\beta_{2} M$ excretion supports the case for dropping this measurement in the assessment of renal function $^{13}$ because of the impractability of routinely administering alkali before collecting urine specimens.

Our findings suggest that more than one mechanism may be responsible for the increased excretion of the constituents measured. It has previously been established that in patients with renal failure the plasma concentrations of RBP, $a_{1} \mathrm{M}$, and $\beta_{2} \mathrm{M}$ are increased, ${ }^{14-18}$ and assay of serum low molecular weight proteins has been proposed to detect and monitor changes of the glomerular filtration rate. ${ }^{319}$ The basis of the rise in plasma concentrations is that their main route of elimination is via the glomeruli, final disposal being attributable to catabolism within the renal tubule cells. A raised plasma concentration of the free form of these proteins can be expected to result in their increased filtration by glomeruli that remain functional and this in turn could lead to saturation of the tubular reabsorptive capacity of such intact nephrons and consequent increased urinary loss. Our findings relating the excretion of RBP, $a_{1} M$ and $\beta_{2} M$ to plasma creatinine concentrations support earlier suggestions that such a mechanism might account for the increased low molecular weight protein output found when the plasma creatinine concentration exceeds $200 \mu \mathrm{mol} / \mathrm{l}^{2}{ }^{15}$

Patients with chronic glomerulonephritis, chronic pyelonephritis, and systemic lupus erythematosus have been reported as having increased serum $\beta_{2} \mathrm{Gl}$ concentrations, ${ }^{20}$ but we have now shown that when the plasma creatinine is raised the plasma $\beta_{2} \mathrm{G} 1$ concentration almost always exceeds the upper limit of the reference range. The exceptions seen in fig 2 might well be heterozygotes for a $\beta_{2} \mathrm{G} 1$ gene which depresses the plasma concentration and is known to occur with a prevalence of about $5 \%$ in the caucasian population. ${ }^{21}$ This finding, together with our observation that increased urinary output of $\beta_{2} \mathrm{G} 1$ consistently occurs when the plasma creatinine exceeds $200 \mu \mathrm{mol} /$ l, suggest that it is handled by the kidney in a similar way to the low molecular weight proteins. It might not be expected to be filtered so readily because it has a molecular mass of 50 kilodaltons, ${ }^{22}$ but it has a range of isoelectric points which are relatively high and so it is probably retarded less than more anionic proteins by the glomerular charge barrier. ${ }^{6}$

The increase of urinary excretion of low molecular weight proteins and $\beta_{2} \mathrm{G} 1$ found in some of our subjects with plasma creatinine concentrations within the reference range is unlikely to be explained by an overflow mechanism. One possibility is that there might be competition from albumin and other proteins for reabsorption by the proximal tubule cells. In rats Bernard et al have clearly shown that small and large proteins can compete for renal uptake and have postulated that there are common reabsorption sites for which proteins exhibit different affinities depending on their charge, size, and configuration. ${ }^{23}$ However, Mutti et al found no relation between albumi- 

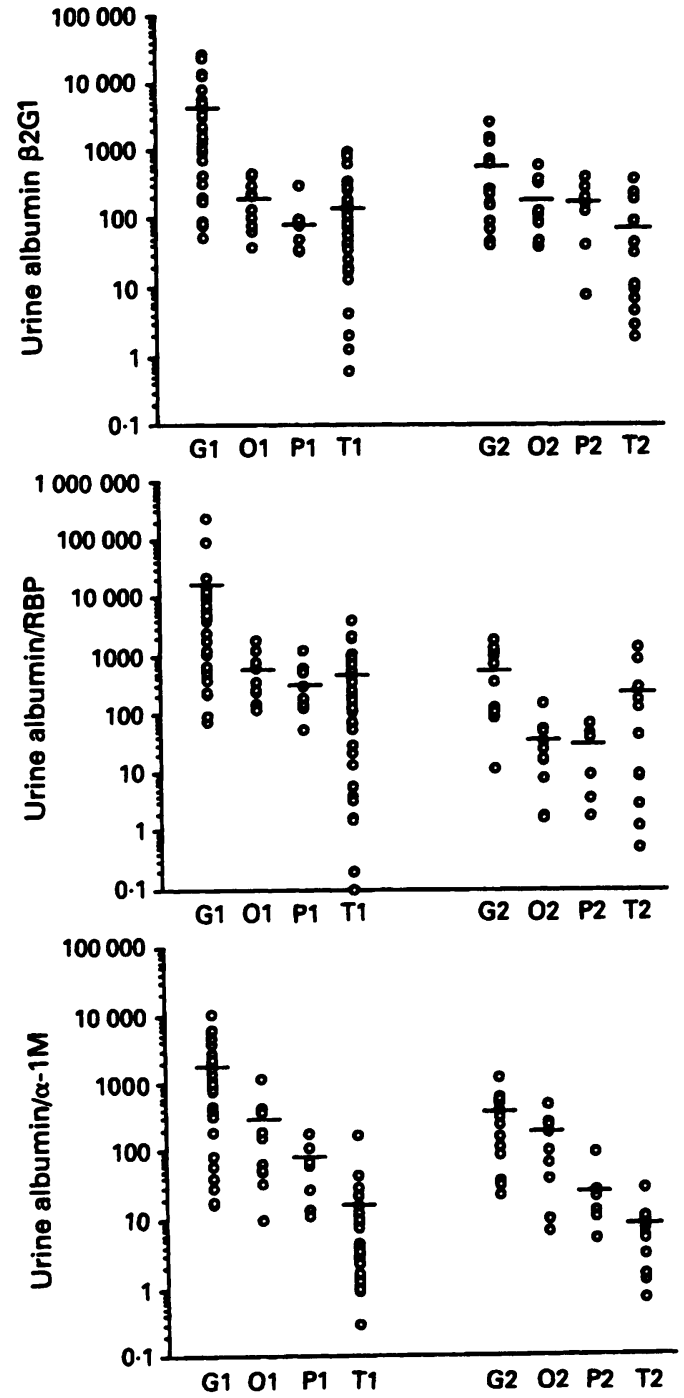

Figure 4 Ratios plotted on logarithmic scales of the excretion of albumin to $\beta_{2} G 1$, to $R B P$ and to $a_{1} M$ among patients with plasma creatinine concentrations under (G1, $O 1, P 1, T 1)$ and over $200 \mu \mathrm{molll}(G 2, O 2, P 2, T 2)$ Groups $G 1$ and $G 2$ comprise 36 and 14 patients with primary glomerular pathology; groups $\mathrm{O} 1$ and 02,11 and 10 patients with obstructive nephropathy; groups P1 and $\mathrm{P} 2$, eight and seven with polycystic kidney disease; and groups $T 1$ and T2, 42 and 12 with renal tubular malfunction. Horizontal lines indicate mean values.

nuria and low molecular weight proteinuria among diabetic patients, ${ }^{24}$ and recently Bernard et al, studying similar patients, produced evidence that suggested that there are sites where albumin selectively competes with Protein-1 but not RBP. ${ }^{25}$

An alternative explanation for the increased loss of low molecular weight proteins and $\beta_{2} \mathrm{Gl}$ among the patients with primary glomerular pathology and a plasma creatinine concentration below $200 \mu \mathrm{mol} / \mathrm{l}$ is that it results from diminution in the ability of the proximal tubule cells to bind and incorporate these proteins into endocytic vesicles or to hydrolyse them within lysosomes. The increase in NAG excretion found in so many of these patients would be consistent with the disease process having produced injury to the proximal tubule cells. Increased glomerular filtration of protein by itself can seemingly cause tubular pathology, because patients with nephrotic syndrome due to minimal change glomerulonephritis have large lipid and protein laden vacuoles within their proximal tubule cells. The correlation we observed between albumin excretion and NAG loss would be consistent with proteinuria causing tubular injury but could also result from the primary disease process in other ways.

Our findings regarding NAG excretion are as expected: increased urinary NAG has previously been reported among patients with various forms of renal disease, ${ }^{426}$ diabetes with microalbuminuria, ${ }^{28}$ and essential hypertension. ${ }^{29}$ The conventional view would be that the increase of NAG represents enzyme that has escaped from the lysosomes of damaged proximal renal tubule cells. In those patients with considerable albuminuria the increase could conceivably represent escape of the 140 kilodalton enzyme into the glomerular filtrate, particularly in those with diabetes or atherosclerosis in whom increased plasma concentrations may have been present. ${ }^{30}$ However, the demonstration that the isoenzyme pattern in the urine in glomerulonephritis differs from that of the plasma, ${ }^{4}$ suggests that NAG excretion reflected the direct escape of enzyme from tubule cells injured by the primary disease process.

The ratios of the excretion of albumin to that of the other proteins measured provided the most effective means of differentiating between patients whose renal disease was of glomerular origin and those where tubular disease was primary. As would be expected, high ratios were found in the former and low ratios in the latter. The ratios of albumin: $\beta_{2} G 1$ gave better discrimination than the ratios of albumin: RBP; albumin: $\beta_{2} \mathrm{G} 1$ ratios of less than 40 were only found in patients with primary tubular disease and ratios greater than 1000 were only found in those with primary glomerular pathology. The best discrimination with least overlap was given by ratios of albumin: $a_{1} \mathbf{M}$; ratios less than 17 and greater than 160 correlated exactly with the primary site of pathology in 61 of the $78(81 \%)$ patients with a plasma creatinine of less than $200 \mu \mathrm{mol} / 1$, and in 19 of $26(73 \%)$ with a plasma creatinine concentration above $200 \mu \mathrm{mol} / 1$. Ratios between the discriminating values may point to some reduction in function in both areas of the nephron and in this context it is of interest that nearly all the ratios in the patients with obstructive nephropathy and polycystic kidney disease were included within the zone of overlap, because this corresponds with what is known of the development of these conditions. Finding overlap in the ratios of those classified as having primary glomerular or tubular pathology fits with the concept that regardless of where the pathological process starts other parts of the nephron are liable to be affected.

This work was supported by a grant from the Locally Organised Research Scheme of the North East Thames Regional Health uthority. We also thank Dr M A Mansell, Professor and Dr F D Thompson for permission to study their patients. 
Maack T, Johnson V, Kau ST, Figueiredo J, Sigulem D. Renal filtration, transport, and metabolism of lowmolecular-weight proteins: a review. Kidney Int molecular-weight

2 Bernard A, Vyskocyl A, Mahieu P, Lauwerys R. Effect of renal insufficiency on the concentration of free retinolbinding protein in urine and serum. Clin Chim Acta 1988;171:85-94.

3 Itoh Y, Kawai T. Human $a_{1}$-microglobulin: its measuremen and clinical significance. F Clin Lab Anal 1990;4: 376-84.

4 Hultberg B, Ravnskov U. The excretion of $\mathrm{N}$-acetyl$\beta$-glucosaminidase in glomerulonephritis. Clin Nephrol 1981;15:33-8.

5 Lapsley M, Sansom PA, Marlow CT, Flynn FV, Norden AGW. $\beta_{2}$-glycoprotein-1 (apolipoprotein $\mathrm{H}$ ) excretion in chronic renal tubular disorders: a comparison with other protein markers

6 Norden AGW, Fulcher LM, Lapsley M, Flynn FV. Excretion of $\beta_{2}$-glycoprotein-1 (apolipoprotein $H$ ) in renal tubular disease. Clin Chem 1991;37:74-7.

7 Sansom PA, Marlow CT, Lapsley M, Flynn FV. A sandwich enzyme-linked immunosorbent assay for $\beta_{2}$-glycoprotein 1. Ann Clin Biochem 1991;28:283-9.

8 Topping MD, Forster HW, Dolman C, Luczynska CM, Bernard AM. Measurement of urinary retinol-binding protein by enzyme-linked immunosorbent assay, and its application to detection of tubular proteinuria. Clin Chem application to detect

9 Takagi K, Koyamaishi Y, Itoh Y, Enomoto H, Kawai T. Enzyme-immunoassay of human $a_{1}$-microglobulin. $f_{p n} \tilde{f}$ Elin Chem 1981;10:30-9.

10 Yuen CT, Kind PRN, Price RG, Praill PFG, Richardson AC. Colorimetric assay for $\mathrm{N}$-acetyl- $\beta$-D -glucosamindase (NAG) in pathological urine using the $\omega$-nitrostyry substrate: the development of a kit and the compariso of manual procedure with the automated fluorimetric method. Ann Clin Biochem 1984;21:295-300.

11 Evrin P-E, Wibell $L$. The serum levels and urinary excretion of $\beta_{2}$-microglobulin in apparently healthy subjects. Scand I Clin Lab Invest 1972;29:69-74.

12 Davey PG, Gosling P. $\beta$-microglobulin instability in pathological urine. Clin Chem 1982;28:1330-3.

13 Flynn FV. Assessment of renal function: selected developments. Clin Biochem 1990;23:49-54.

14 Scarpioni L, Dall'Aglio PP, Poisetti PG, Buzio C. Retinol binding protein in serum and in urine of glomerular and tubular nephropathies. Clin Chim Acta 1976;68:107-13.

15 Yu H, Yanagisawa Y, Forbes MA, Cooper EH, Crockson RA, MacLennan ICM. Alpha-1-microglobulin: an indicator protein for renal tubular function. 7 Clin Pathol 1983;36:253-9.

16 Cooper EH, Forbes MA, Crockson MA, MacLennan ICM.
Proximal renal tubular function in myelomatosis: observations from the fourth Medical Research Council observations from the fourth Medica
trial. $f$ Clin Pathol 1984;37:852-8.

17 Schardijn GHC, Statius van Eps LW. $\beta_{2}$-microglobulin: its significance in the evaluation of renal function. Kidney In 1987;32:635-41.

18 Wibell L, Evrin P-E, Berggard I. Serum $\beta_{2}$-microglobulin in renal disease. Nephron 1973;10:320-31.

19 Jung K, Schulze B-D, Sydow K, Pergande M, Precht K, Schreiber G. Diagnostic value of low-molecular mas proteins in serum for the detection of reduced glomerular filtration rate. 1 Clin Chem Clin Biochem 1987;25: 499-503.

20 Cohnen G. Immunochemical quantitation of $\beta$-glycoprotein 1 in various diseases. I Lab Clin Med 1970 75:212-6.

21 Sepehrnia B, Kamboh MI, Adams-Campbell LL et al. Genetic studies of human apolipoproteins VIII. Role of the apolipoprotein $\mathrm{H}$ polymorphism in relation to serum ipoprotein concentration. Hum Genet 1989;82:118-22.

22 Schousboe I. Purification, characterisation and identification of an agglutinin in human serum. Biochem Biophys Acta 1979;579:396-408.

23 Bernard A, Viau C, Ouled A, Lauwerys R. Competition between low- and high-molecular-weight proteins for renal tubular uptake. Nephron 1987;45:115-8.

24 Mutti A, Alinovi R, Ghiggeri GM, et al. Urinary excretion of brush-border antigen and plasma proteins in early stages of diabetic nephropathy. Clin Chim Acta 1990; 188:93-100.

25 Bernard AM, Lauwerys RR, Noel A, Vandeleene $B$ Lambert A. Urine Protein 1: a sex-dependent marker of Lambert A. Urine Protein 1: a sex-dependent marker of tubular or

26 Sherman RL, Drayer DE, Leyland-Jones BR, Reidenberg MM. N-acetyl- $\beta$-glucosaminidase and $\beta_{2}$-microglobulin Their urinary excretion in patients with renal paren chymal disease. Arch Intern Med 1983;143:1183-5.

27 Swedenborg $\mathrm{P}$, Hultberg $\mathrm{B}$, Thysell $\mathrm{H}$. Urinary $\beta$-hexosaminidase excretion in polycystic kidney disease. Acta Med Scand 1981;210:471-3.

28 Gibb DM, Tomlinson PA, Dalton NR, Turner C, Shah V, Barratt TM. Renal tubular proteinuria and microalbuminuria in diabetic patients. Arch Dis Child buminuria in

29 Alderman MH, Melcher L, Drayer DE, Reidenberg MM. Increased excretion of urinary $\mathrm{N}$-acetyl- $\beta$-glucosaminidase in essential hypertension and its decline with antihypertensive therapy. $N$ Engl $f$ Med 1983;309: 1213-7.

30 Belfiore F, Napoli E, Vecchio LL, Rabuazzo AM. Increased serum activity of beta-n-acetyl-glucosaminidase in atherosclerosis. Am f Med Sci 1974;268:235-9. 